Balochistan Through Ages, (District Gazeteers), Vol. I - Geography and History; Vol. II - Tribes, Nisa Traders, Quetta 1980.

Balochistan Area Development Project (BALAD): Water Sector: Third Interim Report, Louis Berger International Incorporated, 1989.

Barrow, Chris: Water Resource and Agricultural Development in the Tropics. Longmans, 1989.

Beaumont, P.: Qanats in the Varamin Plain, Iran. Transactions of the Institute of British Geographers 45, 169-179 (1968)

Beaumont, P.: A Traditional Method of Ground Water Extraction in the Middle East. Ground Water 11, 23-30 (1973)

Beaumont, P.: Water Resource Development in Iran. Geographical Journal 140 (1974)

Beckett, P.H.T.: Qanats in Persia. Iran Society Journal 1, 125-133 (1952)

Beckett, P.H.T.: Qanats around Kirman. Journal Royal Cent. Asian Society 40, 47-58 (1953)

English, P.W.: The Origin and Spread of Qanats in the Old World. Proceedings American Philosophical Society 112, 170-181 (1968)

Fox, Cyril: The Geology of Water Supply. London 1949.

Caponera, D.A.: Water Laws in Moslem Countries. FAO Development Paper 43, FAO, Rome 1954.

Cressey, G. B.: Qanats, Karez and Foggaras. Geographical Review 48, 27-44 (1958)

Government of Balochistan: Agricultural Statistics of Balochistan, 1987-88. Quetta.

Government of Balochistan: Activities of Irrigation and Power Department. Quetta 1986.

Government of Pakistan: Agricultural Statistics of Pakistan, 19901991. Economic Wing, Islamabad 1992.
Kahlown, M.A.; Khalil, M.; Munir, M.: Karez Irrigation in Balochistan, Pakistan Water and Power Development Authority, 1987.

Kazmi, A.H.; Reza, S. Q.: Water Supply of Quetta Basin, Quetta, Balochistan (Pakistan). Records of the Geological Survey of Pakistan 20, 2, Quetta (1970)

Khan, Fazle Karim; Nawaz, M.: Land Use in Kaurjo - Karez Irrigation in the Oases of Kech Vally, Makran Division. In: Tirmizi and Perlins (eds.), Societal Dynamics and Irrigation Systems. Pakistan Council of Research in Water Resources, Islamabad 1989.

Khan, Fazle Karim; Nawaz, M.: Irrigation and Land Use in the Kech Valley, Makran, Department of Geography, University of Balochistan, Quetta 1990. (Unpublished)

Khan, Fazle Karim; Nawaz, M.: Water Resources: An Environmental Crisis in Balochistan. National Seminar on Resource Development and its Management in Arid Areas. Pakistan, Council of Research in Water Resources Quetta 2, 294-298 (1990)

Kidwai, Z. U.: Groundwater Exploration and its Development in Balochistan. Indus XV, 12, 28-31 (1984)

Munir, M.; Kahlown, M. A.: Experimental Improvements of Karezes. Pakistan Water and Power Development Authority, 1988.

Rahman, M.: Ecology of Karez Irrigation: A Case of Pakistan. GeoJournal 5, 1, 7-15 (1981)

Shakrullah, Arif S.M.; Khan, B.: The Diffusion of Tubewell Technology and Karez Abandonment in Balochistan: A Socioeconomic Perspective. In: Tirmizi and Perlins (eds.), Societal Dynamics and Irrigation Systems, Pakistan Council of Research in Water Resources, Islamabad 1989.

WAPDA: Groundwater Levels during 1967-1988 in Quetta Valley. Basic Data Release No. 1, Hydrology Project, Quetta 1988.

Wulff, H.E.: Qanats in Iran. Scientific American 218, 94-105 (1968)

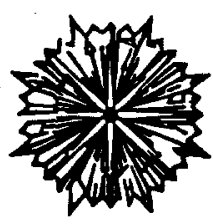

\section{The Association of Muslim Social Scientists}

A non-profit, non-political, educational organization

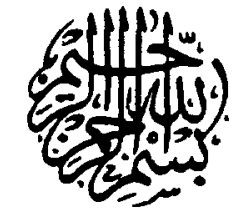

\section{The Twenty-Fourth Annual Conference \\ Chicago, Illinois, October 27-29, 1995}

\begin{abstract}
Announcement
The AMSS 24th Annual Conference will be held at the EastWest University located at 816 S. Michigan Avenue, Chicago. IL 60605 , during the weekend of October 27-29, 1995 (FridaySunday).

In the interest of focus, the theme of the conference will be "Islam and Muslims in the 20th Century: A Multi-Disciplinary Perspective." This is not to preclude other proposals, especially in the form "of panels. The AMSS Executive Board encourages all scholars, Muslims and non-Muslims, with expertise on Islam and Muslim societies to submit proposals of their papers.
\end{abstract}

The deadline for submissions of abstracts (250-300 words only) is June 30, 1995. Final papers must be postmarked on or before August 31, 1995. Abstracts of all accepted presentations will be printed and distributed of participants at the conference. The AMSS plans to include completed papers in the proceedings of the conference.

Participants of the conference are urged to emphasize the scholary standards of a professional convention. The AMSS will incur the board and lodging expenses for all presenters. Papers of the three best students will be selected for recognition awards and subsequent inclusion in the American Journal of Islamic Social Sciences (AJISS).

All correspondence in this regard should be addressed to: Dr. Salahuddin Malik AMSS Program Chairman 8 Leeward Lane Rochester, NY 14618

We await your submissions! Wassalam. 